\title{
Occurrence, Risk Assessment and Wound Healing Approach of Myiasis in Cattle and Goat in Chittagong, Bangladesh
}

\author{
Md. Samun Sarker ${ }^{*}$, Arup Sen ${ }^{1}$, Md. Ahaduzzaman ${ }^{2}$, Md. Abu Sayeed ${ }^{2}$, Zamila Bueaza \\ Bupasha $^{1}$, Jannatul Ferdous ${ }^{3}$, Shumaila Manzoor ${ }^{4}$, Nasir Uddin ${ }^{5}$
}

\begin{abstract}
${ }^{1}$ Department of Microbiology and Veterinary Public Health; ${ }^{2}$ Department of Medicine and Surgery; ${ }^{3}$ Department of Genetics and Animal Breeding, Chittagong Veterinary and Animal Sciences University (CVASU), Bangladesh; ${ }^{4}$ National Veterinary Laboratory, Park road, Islamabad, Pakistan; Program officer, ${ }^{5}$ Wild Team, Bangladesh.
\end{abstract}

\begin{abstract}
The present study was conducted to determine the clinical prevalence of myiasis in cattle and goats at three veterinary hospitals of Chittagong and Cox's Bazar district, Bangladesh. During the study period overall 2270 cases were observed of which 91 cattle and goats were affected with myiasis. The disease was diagnosed by their clinical history and signs. By using a structured questionnaire several factors like rearing system, species, breed, age, sex and predisposing factors, body part affected and antimicrobials used to treat myiasis wound of each individual case were recorded and subsequently analyzed. The overall proportionate prevalence of myiasis was $4.09 \%$ of which $1.67 \%(\mathrm{n}=38)$ in cattle and $2.42 \%(\mathrm{n}=55)$ in goat whereas proportionate prevalence in Patiya, Ruma and SAQTVH was 5.52\% $(\mathrm{N}=670), 3.65 \%(\mathrm{~N}=1150)$ and $2.55 \%(\mathrm{~N}=550)$. Younger goat less than 1 year of age had $34(71.4 \%)$ prevalence along with a semi-intensive rearing system $38(69.09 \%)$ showed significantly highest infestation rate. In case of cattle the highest prevalence was found in cross breed $18(56.2 \%)$ but $23(41.82 \%)$ in case of Jamunapari breed of goat. Frequency of myiasis was higher in the vagina (13.99\%) than other body regions and the most common predisposing factors were diarrhoea (17\%), parturition (12\%) and omphalitis (15\%). Hematological parameters revealed that eosinophils were the predominated circulation cells. During the treatment of myiasis wound of cattle and goats penicillin and streptomycin combination was used in maximum $38(40.86 \%)$ cases. These findings bring out the wound healing approach, management and treatment of myiasis in cattle and goat within different topography in Chittagong, Bangladesh.
\end{abstract}

Keywords | Fly strike, Maggot infestation, Hematology, Diseases, Antimicrobials

Editor | Muhammad Abubakar, National Veterinary Laboratories, Islamabad, Pakistan.

Received | October 07, 2016; Accepted | October 15, 2016; Published | October 22, 2016

*Correspondence | Md. Samun Sarker, Department of Microbiology and Veterinary Public Health, Chittagong Veterinary and Animal Sciences University (CVASU), Bangladesh; Email: samun_cvasu@yahoo.com

Citation | Sarker MS, Sen A, Ahaduzzaman M, Sayeed MA, Bupasha ZB, Ferdous J, Manzoor S, Uddin N. (2016). Occurrence, risk assessment and wound healing approach of myiasis in cattle and goat in Chittagong, Bangladesh. Res. J. Vet. Pract. 4(4): 60-65.

DOI | http://dx.doi.org/10.14737/journal.rjvp/2016/4.4.60.65

ISSN | 2308-2798

Copyright $(92016$ Sarker et al. This is an open access article distributed under the Creative Commons Attribution License, which permits unrestricted use, distribution, and reproduction in any medium, provided the original work is properly cited.

\section{INTRODUCTION}

$\mathrm{M}$ yiasis is the invasion of any part of the body by the Diptera flies larvae that grow inside the host while feeding on its tissue or body fluids (Nazani et al., 2011). In more specifically Zumpt (1965) defined Myiasis as "the infestation of live vertebrate animals with dipterous larvae, which at least for a certain period, feed on the host's dead or living tissues, liquid body substances, or ingested food". In general livestock population may be infected by many infectious and parasitic diseases of which myiasis is one of the most familiar arthropod infested disease. Virtually flies that caused myiasis belong to the Calliphoridae, Sarcophagidae, Hypodermatidae, Oestridae and Gasterophilidae families (Serra-Freire and Mello, 2006). The disease is worldwide distributed and affects numerous animal species including human. Among the animal species the most frequent host for myiasis are cattle and goat (46.4\%) followed by dogs (15.3\%), humans (14.7\%), pigs (6\%), horses (4\%) and sheep (1\%) (Berm'udez et al., 2007). It is important 
to realize ruminants frequently sustain different types of wounds and it appears from the clinical impression that a good percentage of these wounds are complicated with maggot infestation. This problem in cattle and goat is more in the field condition, particularly in the season of fly prevalence (Juyena et al., 2014). Of course myiasis still remains as an unresolved problem for animal health and production in terms of severe economic losses to the livestock industry in not only developing countries but also developed territories (Otranto and Colwell, 2008).

Moreover, report of economic losses in leather industries of Iran shown devaluation of goat hides by warble fly myiasis infestation about 95,800 US\$ per year (Shemshadi et al., 2014). The diagnostic investigation is not so easy due to etiology of the disease itself, which can sometimes be caused by several dipterans agents, giving rise to various pathological processes, which might lead to incomplete registration of a case (McGarry, 2014). Thereupon field diagnosis is usually made on the basis of wound history, close examination of the wound, characteristic odor and brownish exudation from the wound and demonstration of maggots. The therapeutic approaches mainly comprise dressing of wounds with tincture of iodine, oil of turpentine or other antibacterial or vermicide agents.

Additionally, there has been seldom reported on the clinical management of myiasis in cattle and goat in Chittagong region of Bangladesh. Considering the facts this study was conducted to estimate the proportionate prevalence, distribution of affected body part, hematological parameters and antimicrobial drug used to cure the wound following the exclusion of maggot from the wound in cattle and goats.

\section{MATERIALS AND METHODS}

\section{Study Design}

Three months long (February-April, 2014) cross sectional studied was conducted at random selected Ramu upazila veterinary hospital of Cox's Bazaar district and S.A. Quadery teaching veterinary hospital (SAQTVH) and Patiya upazila veterinary hospital of Chittagong district, Bangladesh. Clinical myiasis cases of cattle and goats were studied over the study period.

\section{Data Collection}

Rearing system, species, breed, age and sex of each individual case were recorded in structural questionnaire. Cases were diagnosed on clinical signs of developed wound infested with maggots and affected regions of each individual case were noted together with drugs prescribed for the management of myiasis wound.

\section{Evaluation of Blood Parameters}

Hematological analysis of a sample was performed on an autohemolyzer within 24 hours of collection of a blood sample in the Department of Physiology, Biochemistry and Pharmacology at Chittagong Veterinary and Animal Sciences University (CVASU), Bangladesh, according to the biochemical analyzer manual (Humalyzer 3000, GermanyR). In total blood was collected from 10 myiasis-goats whose hematological parameters were compared with the reference values.

\section{Data Analysis}

Data were entered into Microsoft office excel-2007, USA and then exported to STATA version-13 (STATA Corporation, College Station, Texas, USA) for statistical analysis. Descriptive analysis was performed on the data of myiasis in relation to different factors. Descriptive analysis was also carried out on the data of myiasis affected regions, hematological parameters and drugs prescribed. Results are presented as frequency and percentage of myiasis against each category of factors. The level of significance was set at $p \leq 0.05$.

\section{RESULTS}

\section{Proportionate Prevalence of Maggot Infesta-} TION

Proportionate prevalence of myiasis in the total population was 4.09\% ( $\mathrm{N}=2270)$, whereas in Patiya, Ruma and SAQTVH it was $5.52 \%(\mathrm{~N}=670), 3.65 \%(\mathrm{~N}=1150)$

Table 1: Proportionate prevalence of myiasis in cattle and goats at SAQTVH and Patiya of Chittagong district and Ruma upazila veterinary hospital of Cox's Bazaar district of Bangladesh

\begin{tabular}{|c|c|c|c|c|c|c|c|c|}
\hline Hospital & $\begin{array}{l}\text { No of } \\
\text { cases } \\
\text { (n) }\end{array}$ & $\begin{array}{l}\text { Total } \\
\text { population } \\
(\mathrm{N})\end{array}$ & $\begin{array}{l}\text { Proportionate } \\
\text { Prevalence } \\
\text { (\%) }\end{array}$ & $\begin{array}{l}\text { Proportionate } \\
\text { Prevalence } \\
(\%)(\mathrm{N}=2270)\end{array}$ & Species & $\begin{array}{l}\text { No of } \\
\text { cases (n) }\end{array}$ & $\begin{array}{l}\text { Proportionate } \\
\text { Prevalence } \\
\text { (\%) }\end{array}$ & $\begin{array}{l}\text { Proportionate } \\
\text { Prevalence } \\
(\%)(\mathrm{N}=2270)\end{array}$ \\
\hline \multirow[t]{2}{*}{ SAQTVH } & 42 & 1050 & $4.0(\mathrm{~N}=1050)$ & 1.85 & Cattle & 16 & $1.52(\mathrm{~N}=1050)$ & 0.70 \\
\hline & & & & & Goat & 26 & $2.48(\mathrm{~N}=1050)$ & 1.15 \\
\hline \multirow{2}{*}{$\begin{array}{l}\text { Ramu } \\
\text { UVH }\end{array}$} & 14 & 550 & $2.55(\mathrm{~N}=550)$ & 0.62 & Cattle & 5 & $0.91(\mathrm{~N}=550)$ & 0.22 \\
\hline & & & & & Goat & 9 & $1.64(\mathrm{~N}=550)$ & 0.39 \\
\hline \multirow[t]{2}{*}{ Patiya } & 37 & 670 & $5.52(\mathrm{~N}=670)$ & 1.63 & Cattle & 16 & $2.39(\mathrm{~N}=670)$ & 0.70 \\
\hline & & & & & Goat & 21 & $3.13(\mathrm{~N}=670)$ & 0.93 \\
\hline Total & 93 & 2270 & & $4.09(\mathrm{~N}=2270)$ & & 93 & & \\
\hline
\end{tabular}


and $2.55 \%(\mathrm{~N}=550)$, respectively. The overall proportionate prevalence in cattle and goat was $1.67 \%(n=38)$ and $2.42 \%$ $(n=55)$. In Potiya proportionate prevalence of myiasis in cattle was $0.70 \%(\mathrm{~N}=2270)$ and $0.93 \%(\mathrm{~N}=2270)$ in goat. On the other hand In Ramu 0.22\% (N=550) and 1.64 $(\mathrm{N}=550)$ in cattle and goat respectively. Finally, in SAQT$\mathrm{VH}$, it was $1.52(\mathrm{~N}=1050)$ in cattle and $2.48(\mathrm{~N}=1050)$ in goat (Table 1).

\section{Cases (\%)}

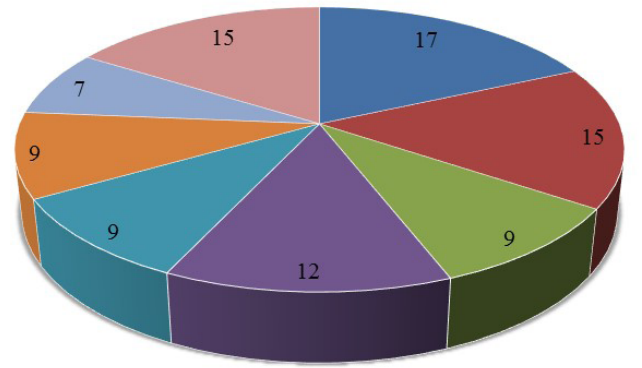

- Diarrhea

- Omphalitis

- Castration

- Parturition

$=\mathrm{FMD}$

- Ecthyma

$=$ Dog biting

$=$ Injury

Figure 1: Major diseases that predisposes maggot infestation in cattle and goats

\section{Frequency of Myiasis According to Variables}

Prevalence of myiasis in cattle in both intensive (50\%) and semi intensive system (50\%) was equal. No significant difference was observed in prevalence between breed, age and sex of cattle. In case of goats, myiasis was significantly higher in semi intensively reared goats than those reared in intensive farming systems $(\mathrm{p} \leq 0.05)$. The age of the animal showed that the younger goats less than one year of age had significantly higher prevalence rate than the goats older than one year $(\mathrm{p} \leq 0.05)$. But breed and sex of the animal did not shown significant difference in the prevalence of myiasis (Table 2).

\section{Diseases that Predispose the Occurrence of MYIASIS}

Major diseases or their conditions found positive for inclined to the cattle and goats for maggot infestation were diarrhea (18.28\%), omphalitis (16.13\%), castration (9.68\%), parturition (12.90\%), Foot and mouth disease (FMD) (9.68\%), contagious ecthyma (9.68\%), dog biting $(7.52 \%)$ and different type of injury (16.13\%) (Figure 1).

\section{Affection of Body Parts by Myiasis}

Total 93 cases were recorded of which maggot infestation was found in the vagina (13), tail (12), umbilicus (11), inter digital space (10), inguinal region (8), mouth (8), ear (7), mammary gland (6), scrotum (6), base of horn (4), penis (4) and shoulder (4) (Table 3).

\section{Hematological Parameters of Myiasis Affected GOATS}

The total erythrocyte count was $12.52 \pm 0.67$ million per cubic milliliter whereas the packed cell volume (PCV) and hemoglobin $(\mathrm{Hb})$ was $25.44 \pm 0.71 \%$ and $8.8 \pm 0.30$ gram percent respectively. Total leukocyte count (TLC) was found $10.73 \pm 0.77$ thousand per cubic milliliter of blood besides the neutrophil, eosinophil, basophile, lymphocyte and monocyte counts was $37 \pm 2.27,18.67 \pm 1.34,0.33 \pm 0.23$, $40 \pm 2.65$ and $4.22 \pm 0.92$ respectively (Figure 2 ).

\section{Treatment of Myiasis Wound}

Myiasis was managed by removing the maggots with the application of oil of turpentine. In addition, a wide range of antimicrobial drugs was used to prevent secondary infection

Table 2: Frequency distribution of myiasis according to rearing system, breed, age and sex of the cattle and goats n (\%)

\begin{tabular}{|c|c|c|c|c|c|c|c|c|c|}
\hline \multirow[t]{2}{*}{ Species } & \multicolumn{2}{|c|}{ Rearing system } & \multicolumn{3}{|l|}{ Breed } & \multicolumn{2}{|l|}{ Age (Year) } & \multicolumn{2}{|l|}{ Sex } \\
\hline & Intensive & $\begin{array}{l}\text { Semi- } \\
\text { intensive }\end{array}$ & Local & $\begin{array}{l}\text { Red Chittagong } \\
\text { Cattle }\end{array}$ & Cross & $\begin{array}{l}\text { Less than or } \\
\text { equal to } 1\end{array}$ & $\begin{array}{l}\text { More than } \\
1\end{array}$ & Male & Female \\
\hline Cattle & $19(50)$ & $19(50)$ & $10(26.32)$ & $10(26.32)$ & $18(56.2)$ & $17(44.74)$ & $21(55.26)$ & $18(47.37)$ & $20(52.63)$ \\
\hline$P$ value & 0.99 & & 0.08 & & & 0.37 & & 0.65 & \\
\hline Goat & Intensive & $\begin{array}{l}\text { Semi- } \\
\text { intensive }\end{array}$ & $\begin{array}{l}\text { Black Bengal } \\
\text { Goat }\end{array}$ & Jamunapari & Cross & $\begin{array}{l}\text { Less than or } \\
\text { equal to } 1\end{array}$ & $\begin{array}{l}\text { More than } \\
1\end{array}$ & Male & Female \\
\hline & $17(30.91)$ & 38 (69.09) & $17(30.91)$ & $23(41.82)$ & $15(27.27)$ & $34(71.4)$ & $21(28.6)$ & $27(47.6)$ & $28(52.4)$ \\
\hline$P$ value & 0.00 & & 0.24 & & & 0.01 & & 0.85 & \\
\hline
\end{tabular}

Table 3: Body part affected by maggot infestation during the study period in cattle and goats

\begin{tabular}{llllllllllllll} 
Parameter & \multicolumn{11}{c}{ Name of organs } \\
& A & B & C & D & E & F & G & H & I & J & K & L & Total \\
No of cases & 8 & 7 & 13 & 12 & 11 & 4 & 6 & 10 & 4 & 8 & 4 & 6 & 93 \\
\% on total & 8.60 & 7.53 & 13.99 & 12.90 & 11.83 & 4.30 & 6.45 & 10.75 & 4.30 & 8.60 & 4.30 & 6.45 & 100 \\
A, Mouth; B, Ear; C, Vagina; D, Tail; E, Umbilicus; F, Penis; G, Scrotum; H, Inter digital space; I, Horn; J, Inguinal region; K, \\
Shoulder; L, Mammary gland
\end{tabular}


during the wound healing process. Significant variation was found to select the antimicrobial agents $(p \leq 0.05)$. In general penicillin and streptomycin combination was the most frequent $(40.86 \%)$ used drug followed by Oxytetracycline (29.03\%), amoxicillin (19.35) and ciprofloxacin (10.76\%) (Table 4).

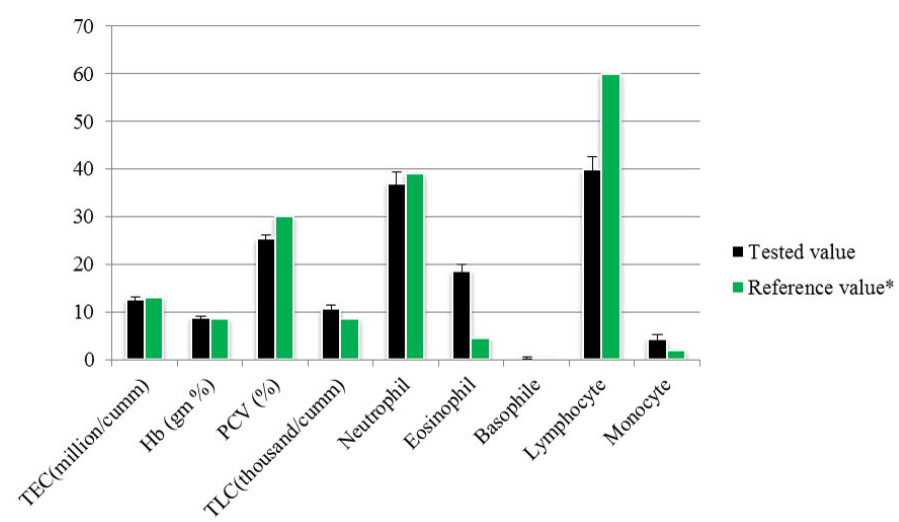

Figure 2: Different blood parameter values of maggot wounded goats (Goatlink, 2009)

Table 4: Frequency distribution of antimicrobial drug prescribed against secondary bacterial infection in clinical myiasis

\begin{tabular}{|c|c|c|}
\hline Antibiotics (Group) & n (\%) & Pvalue \\
\hline Amoxicillin ( $\beta$ Lactam) & $18(19.35)$ & \multirow{4}{*}{0.00} \\
\hline Ciprofloxacin (Fluroquinolone) & $10(10.76)$ & \\
\hline Oxytetracycline (Tetracycline) & $27(29.03)$ & \\
\hline $\begin{array}{l}\text { Penicillin + Streptomycin } \\
(\beta \text { Lactam + Aminoglycoside })\end{array}$ & $38(40.86)$ & \\
\hline
\end{tabular}

\section{DISCUSSION}

Presence of fly larvae in animal body could reflect a present exposure to the disease myiasis. In this study, ninety three myiasis cases were observed in which proportionate prevalence of myiasis in cattle and goat was $1.67 \%$ and $2.42 \%$, whereas, Berm'udez (2007) recorded the most infested (46.4\%) host for myiasis were cattle and goat. Alahmed (2004) reported 3\% out of 3129 in Italy and 2\% out of 3712 cases in Riyadh Region, respectively. However, higher prevalence rate than the present study was reported that are $14.71 \%$ among 1964 cases in southeastern part of Iran (Radfar and Hajmohammadi, 2012), 13.1\% out of 1998 in South Iran (Shoorijeh et al., 2011), 59.9\% out of 554 in Ethiopia (Gebremedhin, 2011), 40.3\% out of 387 in north-eastern part of Turkey (Arslan et al., 2008), 31.9\% out of 1276 cases in Turkey (Kara et al., 2005), 24\% out of 520 in northern Jordan (Abo-Shehada et al., 2003) and 35.68\% among 1303 cases in northern Mediterranean region of France (Dorchies et al., 2000).

It was pragmatic that cross breed cattle were frequently infested with myiasis than the Red Chittagong and local breed. Similarly, Kara et al. (2005) illustrated as infestation rates of fly larvae was lower in native cattle. On contrary significant variation in prevalence was not found in different goat breed. However, Imtiaz et al. (2014) reported that cross breeds (34.2\%) goats were mostly infected by maggot of a fly.

The infection rate was insignificantly higher in cattle more than one year of age than the lower age group, unlike goats where prevalence was higher in the younger group than the older. Kara et al. (2005) said the intensity of the infestation decreased with the age of cattle then again Arslan et al. (2008) stating that infestation rate up to 1 -years-old was $30.0 \%, 1$ to 3 years-old $40.0 \%$ and older than 3 years old was $52.4 \%$ in cattle. The findings of this research are in line with the findings of Paredes-Esquivel et al. (2012), prevalence in lambs younger than 4 months was significantly more affected than the other age group by the same token Alem et al., (2010) found a prevalence of $O$. ovis in small ruminants of less than 1 year of age was significantly higher than those with greater than 1 year of age.

In this study, there was not any significance influenced by sex of cattle and goats. In like manner infection rate in both sexes were also mentioned by different studies (Gebremedhin, 2011; Scholtz et al., 2011; Shoorijeh et al., 2011; Abo-Shehada et al., 2003). While, Radfar and Hajmohammadi (2012) found that female goats were more significantly affected in comparison to male goats. However, in several studies more cases of myiasis were reported in male than the female animals (Kara et al., 2005; El-Rahman, 2010; Orfanou et al., 2011).

The study exposed that, the frequency of maggot infestation was higher in vagina other more common sites of myiasis recorded were tail, umbilicus and inter-digital space of the hoof. Rahman et al. (2009) explained myiasis occurred in the navel area of newborn calves (27\%), vulva region of recently calved cows (20\%), in the shoulder region (20\%) and in wounds in between the claws. Duro et al. (2007) also reported that umbilical myiasis is well-recognized in animals. Rahman et al. (2009) found myiasis wounds in the umbilicus, vagina, scrotum and shoulder area with cattle at the Veterinary Clinic, Bangladesh Agricultural University, Mymensingh; Gaglio et al. (2011) reported three cases of genital myiasis occurred where the wound in vulva of a goat, scrotum of a ram in Italy.

Maggot wound is believed to sterile until maggot is not removed. Ordinarily the microorganisms associated with myiasis are Staphylococcus spp. (Islam et al., 2015) and tetanus in young kids is common in post myiasis patient if infected with Clostridium tetani predispose by unhygienic management and inappropriate use of antimicrobials (Ahaduzzaman, 2015). It was observed that, in all cases of 
ruminants oil of turpentine was used as a maggot repellent. Several antimicrobial drugs were also used to prevent secondary infection. Overall the drugs of $\beta$ Lactam and the aminoglycoside combined group were used more frequently than other categories of drugs this may be due to convenient availability, price and broad spectrum efficacy of this drug. However, the selection of an aminoglycoside (gentamicin) or fluoroquinolones drug like ciprofloxacin may be an alternative option to check the infection related to multi-drug resistance bacteria from environmental contamination (Ahaduzzaman et al., 2014; Hassan et al., 2014).

\section{CONCLUSION}

From current study, it may be concluded that overall prevalence of myiasis in the total population was 4.09\% $(\mathrm{N}=2270)$. It was observed that both males and females were affected without significant variation. Frequency of maggot infestation was higher in vagina in both cattle and goat. The drugs of streptomycin and penicillin combination were used more frequently to prevent secondary infection. So, proper care during the risk factors control and hygienic management can minimize the infestation level.

\section{ACKNOWLEDGEMENT}

The authors are grateful to the respected officers and members of veterinary hospitals authority and especially for the animal owners for their cordial participation to fill up the questionnaire.

\section{CONFLICT OF INTEREST}

The authors declare that this work has not been influenced by any financial or personal factors.

\section{AUTHOR'S CONTRIBUTION}

All authors contributed equally and approved the final manuscript.

\section{REFERENCES}

-Abo-Shehada MN, Batainah T, Abuharfeil N, Torgerson PR (2003). Oestrus ovis larval myiasis among goats in northern Jordan. Prev. Vet. Med. 59(1-2): 13-19. https://doi. org/10.1016/S0167-5877(03)00058-8

-Ahaduzzaman M (2015). Updates on tetanus toxin: a fundamental approach. J. Adv. Vet. Anim. Res. 2(1): 23-29. https://doi.org/10.5455/javar.2015.b54

-Ahaduzzaman M, Hassan MM, Alam M, Islam SKMA, Uddin I (2014). Antimicrobial resistance pattern against Staphylococcus aureus in environmental effluents. Res. J. Vet. Pract. 2(1): 13-16. https://doi.org/10.14737/journal. rjvp/2014/2.1.13.16

-Alahmed AM (2004). Myiasis in sheep farms in Riyadh region,
Saudi Arabia. J. Egypt. Soc. Parasitol. 34(1): 153-160.

-Alem F, Kumsa B, Degefu H (2010). Oestrus ovis larval myiasis among sheep and goats in Central Oromia, Ethiopia. Trop. Anim. Health Prod. 42(4): 697-703. https://doi. org/10.1007/s11250-009-9477-6

-Arslan MOMO, Kara MM, Gicik YY (2008). Epidemiology of Oestrus ovis infestations in sheep in Kars province of north-eastern Turkey. Trop. Anim. Health Prod. 41: 299305. https://doi.org/10.1007/s11250-008-9190-x

-Berm udez SE, Espinosa JD, Cielo AB, Clavel F, Subía J, Barrios S, Medianero E (2007). Incidence of myiasis in Panama during the eradication of Cochliomyia hominivorax (Coquerel 1858, Diptera: Calliphoridae) (2002-2005). Mem'orias do Instituto Oswaldo Cruz. 102: 675-679. https://doi. org/10.1590/S0074-02762007005000074

-Dorchies P, Bergeaud JP, Tabouret G, Duranton C, Prevot F, Jacquiet $\mathrm{P}$ (2000). Prevalence and larval burden of Oestrus ovis (Linné 1761) in sheep and goats in Northern Mediterranean region of France. Vet. Parasitol. 88(3-4): 269-273. https:// doi.org/10.1016/S0304-4017(99)00215-0

-Duro EA, Mariluis JC, Mulieri PR (2007). Umbilical myiasis in a human new born. J. Perinatol. 27(4): 250-251. https://doi. org/10.1038/sj.jp.7211654

-El-Rahman SSA (2010). Prevalence and pathology of nasal myiasis in camels slaughtered in El-Zawia ProvinceWestern Libya: with a reference to thyroid alteration and renal lipidosis. Global Vet. 4 (2): 190-197.

- Gaglio G, Brianti E, Abbene S, Giannetto S (2011). Genital myiasis by Woblfahrtia magnifica (Diptera, Sarcophagidae) in Sicily (Italy). Parasitol. Res. 109(5): 1471-1474. https://doi. org/10.1007/s00436-011-2431-3

- Gebremedhin EZ (2011). Prevalence of ovine and caprine oestrosis in Ambo, Ethiopia. Trop. Anim. Health Prod. 43(1): 265-270. https://doi.org/10.1007/s11250-010-9687-y

-Goatlink(2009).http://goat-link.com/content/view/204/194/\#. UrJ_-eKFe8w. Retrive: 11.08.2013. Accessible date: 19.12.2013.

-Hassan MM, Amin KB, Ahaduzzaman M, Alam M, Al Faruk MS, Uddin I (2014). Antimicrobial resistance pattern against E. coli and Salmonella in layer poultry. Res.J. Vet. Pract. 2: 3035. https://doi.org/10.14737/journal.rjvp/2014/2.2.30.35

-Imtiaz MA, Rahman MA, Islam K, Barua M, Alim MA, Chowdhury S, Sikder S (2014). Prevalence and associated risk factors of myiasis in different areas of Chittagong, Bangladesh. Res. J. Vet. Pract. 2(2): 22-27. https://doi. org/10.14737/journal.rjvp/2014/2.2.22.27

-Islam MT, Maruf AA, Mannan MA, Rahman HMR, Tarafder MM, Samad MA, Noman AA, Hossain MB, Rahman MM (2015). Isolation and identification of associated bacteria and maggots from myiasis affected wounds of cattle and goats in Bangladesh. J. Adv. Vet. Anim. Res. 2(2): 95-100. https://doi.org/10.5455/javar.2015.b55

-Juyena NS, Tapon MAH, Ferdousy RN, Paul S, Alam MM (2014). A retrospective study on occurrence of myiasis in ruminants. Prog. Agric. 24(1-2): 101-106. https://doi. org/10.3329/pa.v24i1-2.19110

-Kara M, Arslan MO, Gicik (2005). The prevalence of bovine hypodermosis in Kars province, Turkey. Trop. Anim. Health Prod. 37(8): 617-622. https://doi.org/10.1007/s11250-0054291-2

-McGarry JW (2014). Tropical myiases: neglected and welltravelled. Lancet Infect. Dis. 14(8): 672-674. https://doi. org/10.1016/S1473-3099(14)70830-8 
- Nazni WA, Jeffery J, Lee HL, Lailatul AM, Chew WK, Heo CC (2011). Nosocomial nasal myiasis in an intensive care unit. Malaysian J. Pathol. 33: 53-56.

- Orfanou DC, Papadopoulos E, Cripps PJ, Athanasiou LV, Fthenakis GC (2011). Myiasis in a dog shelter in Greece: epidemiological and clinical features and therapeutic considerations. Vet. Parasitol. 181(2-4): 374-378. https:// doi.org/10.1016/j.vetpar.2011.04.006

- Otranto D, Colwell DD (2008). Biodiversity and extinction versus control of oestrid causing myiasis in Mediterranean area. Parasite. 15: 257-260. https://doi.org/10.1051/ parasite/2008153257

-Paredes-Esquivel C, del Rio R, Monerris M, Borràs D, Laglera LM, Miranda MÁ (2012). The influence of sheep age group on the seasonal prevalence of oestrosis in the island of Majorca. Vet. Parasitol. 186(3-4): 538-541. https://doi. org/10.1016/j.vetpar.2011.11.065

- Radfar MH, Hajmohammadi V (2012). Prevalence of goat warble fly, Przhevalskiana silenus in South-eastern Iran. Sci. Parasitol. 13(2): 73-76.
- Rahman MA, Hossain MA, Alam MR (2009). Clinical evaluation of different treatment regimes for management of myiasis in cattle. Bang. J. Vet. Med. 7(2): 348-352.

-Scholtz AJ, Cloete SW, du Toit E, van Wyk JB, Van der Linde TCA (2011). Survey of the prevalence of blowfly strike and the control measures used in the Rûens area of the Western Cape Province of South Africa. J. S. Afr. Vet. Assoc. 82(2): 107-115. https://doi.org/10.4102/jsava.v82i2.43

-Serra-Freire NM, Mello RP (2006). Entomologia and Acarologia na Medicina Veterinária, $1^{\text {st }}$ edn, Editora LF Livros de Veterinária Ltd.

-Shemshadi B, Bahadori SR, Manteghi HA (2014). Study on economical effect of warble fly in goats in Iran. IJABBR 2(2): 267-271.

-Shoorijeh JS, Tamadon A, Negahban SH, Behjadi MA (2011). Prevalence of Oestrus ovis in goats of Shiraz, southern Iran. Vet. Arch. 81: 43-49.

-Zumpt F (1965). Myiasis in man and animals in the Old World, London. A Textbook for Physicians, Veterinarians and Zoologists. Pp. 267. 